\title{
The Assessment of Blood Glucose Distribution according to the Fasting State and Glycemic Control Indicators for Diabetes Screening
}

\author{
Pil Seung Kwon ${ }^{1}$, Insoo Rheem ${ }^{2}$ \\ ${ }^{1}$ Department of Clinical Laboratory Science, Wonkwang Health Science University, lksan 54538, Korea \\ ${ }^{2}$ Department of Laboratory Medicine, Dankook University Hospital, Cheonan 31116, Korea
}

\section{금식 여부에 따른 혈당치 분포와 당뇨병 선별을 위한 혈당조절지표의 평가}

권필승 ${ }^{1}$, 임인수 $^{2}$

${ }^{1}$ 원광보건대학교 임상병리과, ${ }^{2}$ 단국대학교병원 진단검사의학과

\begin{abstract}
This study analyzed the distribution of the blood glucose level according to the fasting status. Moreover, a relationship was analyzed between fasting blood glucose level and glycemic control indicators. A total of 707 outpatients, who visited Dankook University Hospital, were included and classified into either the fasting group and the non-fasting group. The mean blood glucose level of each group was calculated and analyzed by sex, age, and clinic. In addition, blood glucose, HbA1c, fructosamine, and 1,5-AG were measured in 153 fasting health check-up patients, and the correlation between the blood glucose level and glycemic control indicators was evaluated. Blood glucose averages between the two groups (non-fasting $111.9 \mathrm{vs}$. fasting $103.6 \mathrm{mg} / \mathrm{dL}$ ) were different ( $p<0.05)$; and the mean difference was lower in women $(4.8 \mathrm{mg} / \mathrm{dL})$ than in men $(12.2$ $\mathrm{mg} / \mathrm{dL}$ ). A significant difference of the median glucose values among the age groups was only observed in the non-fasting group (Kruskal-Wallis test, $p<0.01$ ), and not in the fasting group. A 1,5-Anhydroglucitol was estimated to be significantly correlated with the fast blood glucose level in the range of the criteria of impaired fasting glucose (IFG). We presented an assessment of the distribution of blood glucose level in accordance with the fasting status among outpatients, and estimated that 1,5-anhydroglucitol was well correlated with the fasting blood glucose than fructosamine and $\mathrm{HbA1C}$, through the analysis of results of health screening subjects. It is suggested that the use of glycemic indicators that reflect short-term blood glucose control can be used together with the blood glucose measurement in the screening of diabetes mellitus.
\end{abstract}

Key words: Fasting glucose, 1,5-Anhydroglucitol, Glycemic control indicators, Diabetes mellitus

This is an Open Access article distributed under the terms of the Creative Commons Attribution Non-Commercial Licens (http://creativecommons.org/licenses/by-nc/4.0) which permits unrestricted non-commercial use, distribution, and reproduction in any medium, provided the original work is properly cited.

Copyright (C) 2016 The Korean Society for Clinical Laboratory Science. All rights reserved.
Corresponding author: Insoo Rheem Department of Laboratory Medicine, Dankook University Hospital, 201 Manghyang-ro, Dongnam-gu, Cheonan 31116, Korea Tel: 82-41-550-6668 Fax: 82-41-550-7055

E-mail: insoo@dankook.ac.kr

Received: October 22, 2016 Revised $1^{\text {st: }}$ October 28, 2016 Revised $2^{\text {nd }}$ : November 1, 2016

Revised $3^{\text {rd: }}$ : November 2, 2016 Accepted: November 2, 2016

\section{서 론}

20세기 들어와 인류는 획기적인 과학기술의 발달과 더불어 의
학은 많은 발전을 이루었다. 우리나라는 그 동안 경제발전과 건강 보험 제도를 통해 의료 수준의 개선이 이루어졌고 이에 따라 평균 수명이 증가해왔다. 유엔의 2008년 세계 인구 현황 보고서에 따르 
면 2005 2010년 한국인의 평균수명은 79.4세이었고 OECD 자 료에 의하면 2013년 81.9세로 11 위이다. 이와 같은 평균수명의 증 가로 사람들은 질병의 예방 특히 만성질환의 예방에 관심이 증가하 고 있다. 당뇨병은 고혈압과 더불어 대표적인 만성질환으로 다양한 혈관 및 장기에 합병증을 유발하여 예방과 적절한 치료가 중요한 질환이다. 고령화 시대에서 삶의 질은 중요하며, 이를 위한 노력의 하나로서 당뇨병은 조기 진단은 매우 필요하다. 당뇨병은 인슐린이 결핍된 종류인 제 1 형과 인슐린의 저항성, 분비 결손이 특징인 제 2 형으로 분류된다. 전당뇨병은 아직 당뇨병의 임상 증상을 나타내지 는 않으나 혈당 수준이 정상보다 증가되어 있는 상태로 내당능 장 애(impaired glucose tolerance, IGT)와 공복 시 포도당 장애 (impaired fasting glucose, IFG)로 구분된다[1-3]. 1997년 미국 당뇨병학회(American Diabetes Association, ADA)는 공복 시 포 도당 장애 선별 기준을 당뇨병 진단에 추가하였다[4].

당뇨병 진단을 위한 선별 검사는 혈당 농도의 측정과 일정한 기 간 동안의 혈당조절을 의미하는 혈당조절지표 검사로 구분된다. 당 뇨병 진단을 위한 혈당 검사는 공복 혈당, 임의 혈당 검사와 포도당 부하 검사(oral glucose tolerance test, OGTT) 등이 있으며 혈당 조절지표 검사에는 당화혈색소(glycated hemoglobin, HbA1c), 프록토사민(fructosamine), 당화알부민(glycated albumin)과 1,5-anhydroglucitol (1,5-AG)이 있다. 당화혈색소는 2, 3개월의 혈당조절을 반영하며 프록토사민과 $1,5-\mathrm{AG}$ 는 그보다 짧은 2,3 주 와 1 3일의 혈당조절의 결과를 반영한다[5-7]. 당화알부민과 $1,5-\mathrm{AG}$ 는 식후 혈당 또는 고혈당을 더 크게 반영하는 혈당 변동성 (glucose fluctuations) 지표로서 사용될 수 있으며, 1,5-AG는 다 른 혈당조절지표보다 단기간의 변동성을 알 수 있는 혈당변동성 지 표로서 보고되고 있다[7].

본 연구는 금식을 하지 않고 내원한 환자에 대해 당뇨병 선별이 필요한 경우에 대한 대처 방법의 일환으로 시작되었고 혈당조절지 표의 활용을 함께 분석하였다. 임의 혈당과 공복 혈당의 분포 차이 를 비교 평가하였고 혈당 검사와 함께 시행 시 추가 정보를 줄 수 있 는, 단기 혈당 조절 능력을 잘 반영하는 혈당조절지표를 선별하였다.

\section{재료 및 방법}

\section{1. 연구 대상}

본 연구는 외래 환자를 대상으로 금식 여부에 따른 혈당치 분포 의 차이를 분석하였고, 건강검진 대상자의 금식 검체에 대해 혈당 과 혈당조절지표 검사들을 시행하여 공복 혈당과의 상관성을 평가 하였다.

\section{1) 금식 여부에 따른 혈당치 분포의 평가}

단국대학교병원에 외래 진료를 목적으로 내원하여 채혈실을 방 문한 환자 중 금식 여부가 확인된 707명을 대상으로 혈당 검사를 시 행하여 금식 군과 비금식 군으로 나누어 혈당치의 차이를 비교하였 고 성별, 연령별, 그리고 내과(internal medicine)와 비내과 (non-internal medicine)로 임상과 별 차이를 평가하였다.

\section{2) 혈당조절지표와 공복 혈당의 상관성 분석}

혈당조절지표와 공복 혈당의 상관성 분석은 건강검진을 목적으 로 단국대학교병원 산업의학과에 내원한 금식 상태의 153 명을 대 상으로 혈당, 1,5-AG, 프록토사민과 당화혈색소를 측정하였다.

\section{2. 검체 분석}

외래 환자 707 명의 혈당 검사는 환자의 전완정맥(antebrachial vein)에서 검체를 채혈하여 응고가 완료된 후, 원심분리한 혈청을 자동임상화학장비(747 Automatic Analyzer, Hitachi, Tokyo, Japan)로 표준 포도당 산화법에 의하여 측정하였다. 건강검진 대상 자 검체들은 혈중 포도당 농도는 Hexokinase법, 프록토사민은 비 색법(colorimetric assay), 1,5-AG는 효소법의 Lana ${ }^{\mathrm{TM}}$ (Japan Chemistry Medicine, Tokyo, Japan) 시약을 이용하여 Modular analytics (Roche Diagnostics GmbH, Mannheim, Germany)로 측정하였다. 당화혈색소는 Variant II turbo (Bio-Rad, Hercules, $\mathrm{CA}, \mathrm{USA})$ 의 $\mathrm{HPLC}$ 법으로 측정하였다.

\section{3. 평가 방법}

\section{1) 금식 여부에 따른 혈당치 분포의 평가}

외래 환자의 혈당치 분석은 금식 군과 비금식 군에서 각각 평균 과 중앙값 그리고 $95 \%$ 신뢰구간의 혈당치 평균 구간을 추정하였고 성별, 연령별 및 임상과 별로 그차이를 비교하였다. 금식 여부에 따 른 혈당치 차이의 유의성 검증은 당뇨병 환자로 추정되는 극외치들 을 포함한 분석이므로, 윌콕슨 순위합 검증(Wilcoxon rank sum test) 방법으로 5\% 유의수준의 단측검정을 적용하여 중앙값 차이 여부를 평가하였다. 그리고 연령대에 따른 중앙값의 변화를 평가하 기 위하여 비금식 군 계열과 금식 군 계열 각각에서 크루스칼 왈리 스 검정(Kruskal-Wallis test)을 시행하였다.

\section{2) 혈당조절지표와 공복 혈당의 상관성 분석}

당뇨병의 혈당 진단 기준치 초과 $(>125 \mathrm{mg} / \mathrm{dL})$ 구간, $\mathrm{ADA}$ 의 공 복 시 포도당 장애의 선별 범위 $(100 \sim 125 \mathrm{mg} / \mathrm{dL})$ 구간과 그 이하 의 정상치 구간으로 조작적으로 정의하여 분석하였고 혈당 및 혈당 조절지표 간 상관성은 켄달의 일치도 검정으로 평가하였다. 그리고 
각 혈당조절지표의 평균치 차이를 공복 시 포도당 장애 선별 구간 과 정상 참고치 내 $100 \mathrm{mg} / \mathrm{dL}$ 이하 구간에서 비교 평가하였다. 혈 당조절지표의 참고범위는 각각 당화혈색소 $4.0 \sim 6.0 \%$, 프록토사 민 205 285 umol/L, 그리고 1,5-AG $14 \mathrm{mg} / \mathrm{mL}$ 이상으로, 혈당 치의 각 범위 구간에서 혈당조절지표의 양성 결과의 사례 건수를 산출하는데 적용하였다. 통계 분석 및 유의성 평가는 SAS 9.2 (SAS Institute Inc., Cary, NC, USA)를 사용하였다.

\section{결 과}

\section{1. 금식여부에 따른 혈당치의 차이 분석}

금식 여부에 따른 성별, 연령별 및 과별 혈당치 분포는 그림과 같 다(Figs. 1 3). 외래 환자 707명 전체의 혈당의 평균 $110.7 \mathrm{mg} / \mathrm{dL}$, 중앙값 $103.0 \mathrm{mg} / \mathrm{dL}$ 이었고 비금식 군 혈당 평균은 $111.9 \mathrm{mg} / \mathrm{dL}$ (중앙값 $104.0 \mathrm{mg} / \mathrm{dL}$ ), 금식 군은 $103.6 \mathrm{mg} / \mathrm{dL}$ (중앙값 98.0 $\mathrm{mg} / \mathrm{dL}$ )로서 유의한 차이가 있었고(Wilcoxon rank sum test, $p<0.05)$ 남자와 여자 그리고 내과와 비내과에서도 비금식 군과 금
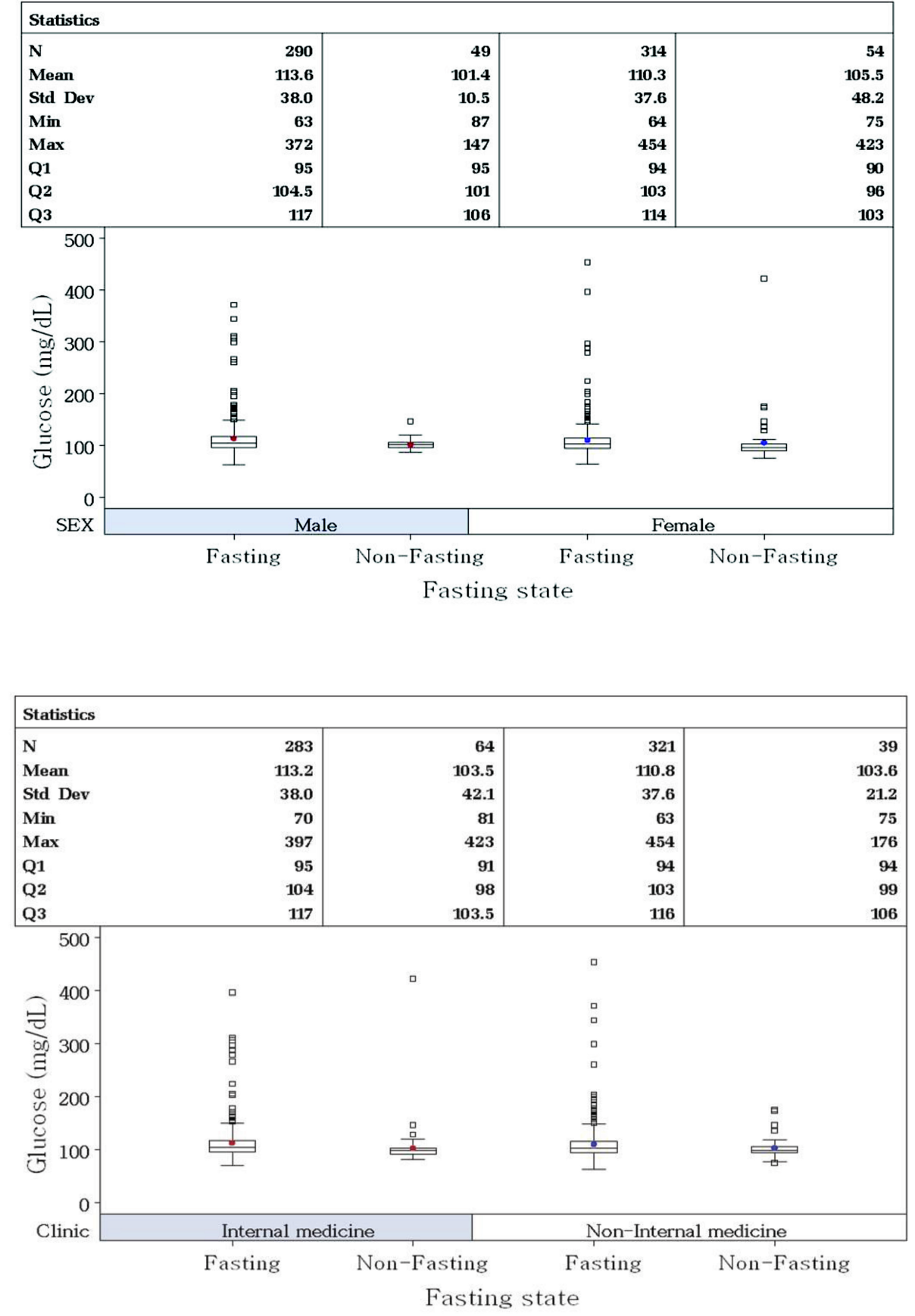

Fig. 1. Distribution of glucose level of outpatients on the fasting status by gender. Abbreviation: Q1, the first quartile (25th percentile); Q2, the second quartile (median); Q3, the third quartile (75th percentile).

Fig. 2. Distribution of glucose level of outpatients on the fasting status by clinics. Abbreviation: See Fig. 1. 


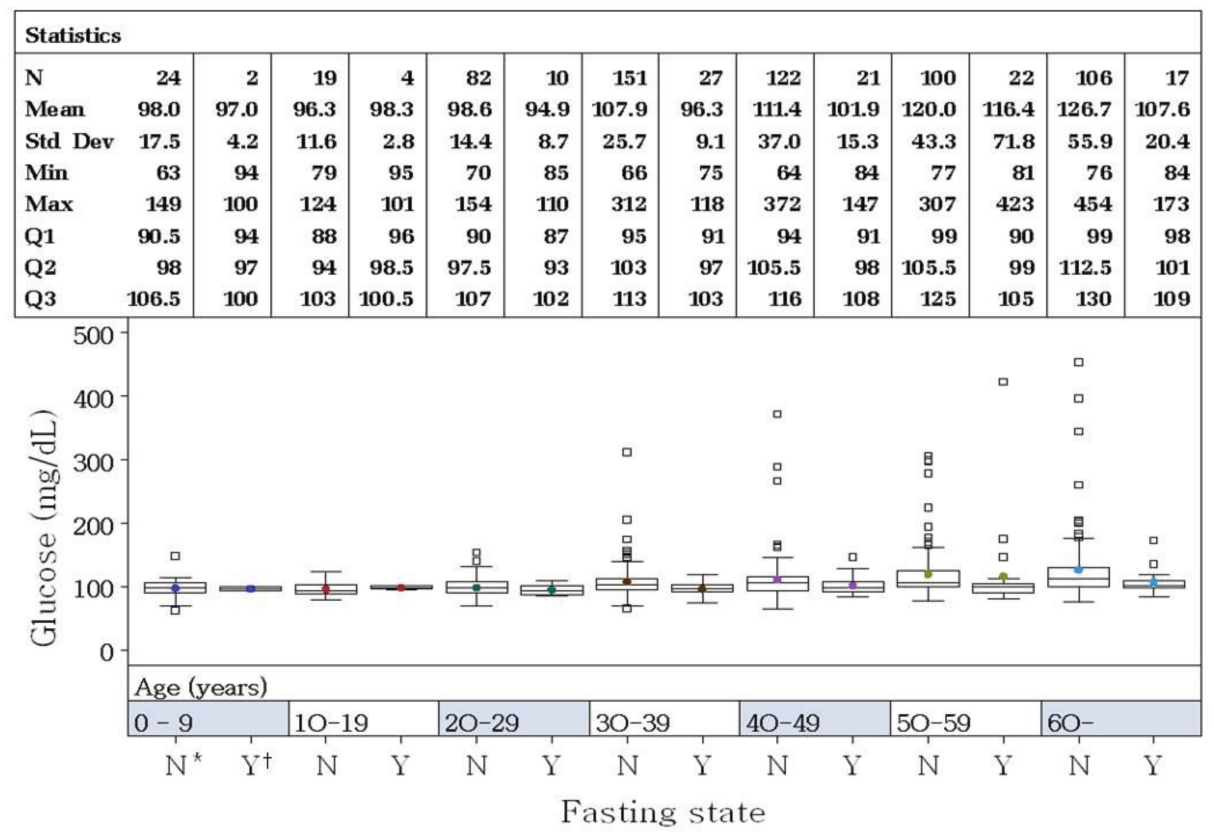

Fig. 3. Distribution of glucose level of outpatients on the fasting status by ages. There was a significant difference in the median glucose values among the age groups only in the non-fasting group (Kruskal-Wallis test, $p<0.01$ ) and not in the fasting group $(p=0.39)$. *Non-fasting state, ${ }^{+}$Fasting-state. Abbreviation: See Fig. 1.

Table 1. Statistics of blood glucose level distribution for outpatients according to the fasting status

\begin{tabular}{|c|c|c|c|c|c|c|c|c|}
\hline Category & Fasting status & No. of patients & Median & Mean $(95 \% \mathrm{Cl})$ & Mean difference & Min & Max & $p$-value \\
\hline \multirow[t]{2}{*}{ All } & $N^{*}$ & 604 & 104.0 & $111.9(108.9 \sim 114.9)$ & \multirow[t]{2}{*}{8.3} & 63 & 454 & \multirow[t]{2}{*}{$<0.001$} \\
\hline & $Y^{\dagger}$ & 103 & 98.0 & $103.6(96.6 \sim 110.5)$ & & 75 & 423 & \\
\hline \multicolumn{9}{|l|}{ Sex } \\
\hline \multirow[t]{2}{*}{ Male } & N & 290 & 104.5 & $113.6(109.2 \sim 118.0)$ & \multirow[t]{2}{*}{12.2} & 63 & 372 & \multirow[t]{2}{*}{$<0.05$} \\
\hline & Y & 49 & 101.0 & $101.4(98.4 \sim 104.4)$ & & 87 & 147 & \\
\hline \multirow[t]{2}{*}{ Female } & N & 314 & 103.0 & $110.3(106.1 \sim 114.5)$ & \multirow[t]{2}{*}{4.8} & 64 & 454 & \multirow[t]{2}{*}{$<0.001$} \\
\hline & Y & 54 & 96.0 & $105.5(92.4 \sim 118.7)$ & & 75 & 423 & \\
\hline \multicolumn{9}{|l|}{ Clinic } \\
\hline \multirow[t]{2}{*}{ IM } & N & 283 & 104.0 & $113.2(108.7 \sim 117.6)$ & \multirow[t]{2}{*}{9.6} & 70 & 397 & \multirow[t]{2}{*}{$<0.001$} \\
\hline & Y & 64 & 98.0 & $103.5(93.0 \sim 114.1)$ & & 81 & 423 & \\
\hline \multirow[t]{2}{*}{ Non-IM } & N & 321 & 103.0 & $110.8(106.6 \sim 114.9)$ & \multirow[t]{2}{*}{7.2} & 63 & 454 & \multirow[t]{2}{*}{$<0.05$} \\
\hline & Y & 39 & 99.0 & $103.6(96.7 \sim 110.5)$ & & 75 & 176 & \\
\hline
\end{tabular}

*Non-fasting state, ${ }^{\dagger}$ Fasting state. $p$-value was calculated by Wilcoxon rank sum test.

Abbreviation: Cl, confidence interval; IM, internal medicine; Non-IM, non-internal medicine.

식 군은 유의한 차이가 있었다(Table 1). 평균치 차이는 여자에서 $4.8 \mathrm{mg} / \mathrm{dL}$ 로서 남자보다 적었다. 연령군별에 따른 외래 환자의 금 식여부에 따른 혈당치의 차이는 Table 2 와 같다. 비금식 군과 금식 군 간 혈당치의 차이는 20 대까지는 적다고 할 수 있었으나 30 대 이 후에는 비교적 큰 차이를 보였다. 윌콕슨 순위합 검정에서 20 대까 지 금식에 따른 혈당치의 유의한 차이가 없는 것으로 평가되었으나 ( $p>0.05$ ) 사례 건수가 적었다(Table 2, Fig. 3). 40 49세 연령대 의 금식 여부에 따른 평균치 차이 평가에서 $p=0.07$ 의 검정 결과는 이 연령대에서 특이적인 양상을 나타냈다기보다는 연구 대상자 수 가 충분하지 못한 경우 표본집단에 따라 통계적 유의성이 달라질 수 있는 경우로 분석하였다.
연령대 별 중앙값의 차이가 있는지를 크루스칼 왈리스 검정 (Kruskal-Wallis test)로 검정한 결과는 비금식 군에서만 연령대 별 유의한 차이가 있었고 $(p<0.01)$ 금식 군에서는 유의하지 않았다 ( $p=0.39$ ) (Fig. 3). 따라서 금식 여부에 따른 혈당 중앙값의 차이는 연령이 증가함에 따라 비금식 군의 평균 혈당치가 높아지는 것에 영향을 받는 것으로 평가하였다.

\section{2. 혈당조절지표와 공복 혈당의 상관성 평가}

Table 3은 각 혈당치 구간에 대한 혈당조절지표들의 양성과 음 성의 결과치 분포이다. 당뇨병 기준인 $126 \mathrm{mg} / \mathrm{dL}$ 이상 구간에서는 모든 지표는 2건의 동일한 사례 $(145 \mathrm{mg} / \mathrm{dL} ; 389 \mathrm{mg} / \mathrm{dL})$ 에서 양 
Table 2. Statistics of blood glucose level distribution for outpatients according to the fasting status by age group

\begin{tabular}{|c|c|c|c|c|c|c|c|c|}
\hline Age group & Fasting status & No. of patients & Median & Mean $(95 \% \mathrm{Cl})$ & Mean difference & Min & Max & $p$-value \\
\hline \multirow[t]{2}{*}{$0 \sim 9$} & $\mathrm{~N}^{*}$ & 24 & 98.0 & $98.0(90.5 \sim 105.4)$ & 1.0 & 63 & 149 & 0.40 \\
\hline & $Y^{\dagger}$ & 2 & 97.0 & $97.0(58.9 \sim 135.1)$ & & 94 & 100 & \\
\hline \multirow[t]{2}{*}{$10 \sim 19$} & $\mathrm{~N}$ & 19 & 94.0 & $96.3(90.7 \sim 101.8)$ & -2.0 & 79 & 124 & 0.21 \\
\hline & Y & 4 & 98.5 & $98.3(93.9 \sim 102.6)$ & & 95 & 101 & \\
\hline \multirow[t]{2}{*}{$20 \sim 29$} & N & 82 & 97.5 & $98.6(95.4 \sim 101.8)$ & 3.7 & 70 & 154 & 0.22 \\
\hline & Y & 10 & 93.0 & $94.9(88.6 \sim 101.2)$ & & 85 & 110 & \\
\hline \multirow[t]{2}{*}{$30 \sim 39$} & $\mathrm{~N}$ & 151 & 103.0 & $107.9(103.8 \sim 112.0)$ & 11.6 & 66 & 312 & $<0.01$ \\
\hline & Y & 27 & 97.0 & 96.3 (92.7 99.9) & & 75 & 118 & \\
\hline \multirow[t]{2}{*}{$40 \sim 49$} & $\mathrm{~N}$ & 122 & 105.5 & $111.4(104.7 \sim 118.0)$ & 9.5 & 64 & 372 & 0.07 \\
\hline & Y & 21 & 98.0 & $101.9(94.9 \sim 108.9)$ & & 84 & 147 & \\
\hline \multirow[t]{2}{*}{$50 \sim 59$} & N & 100 & 105.5 & $120.0(111.4 \sim 128.6)$ & 3.6 & 77 & 307 & $<0.01$ \\
\hline & Y & 22 & 99.0 & $116.4(84.6 \sim 148.2)$ & & 81 & 423 & \\
\hline \multirow[t]{2}{*}{$60 \sim$} & $\mathrm{N}$ & 106 & 112.5 & $126.7(116.0 \sim 137.5)$ & 19.2 & 76 & 454 & $<0.05$ \\
\hline & Y & 17 & 101.0 & $107.6(97.1 \sim 118.1)$ & & 84 & 173 & \\
\hline
\end{tabular}

*Non-fasting state, ${ }^{\dagger}$ Fasting state. $p$-value was calculated by Wilcoxon rank sum test.

Abbreviation: $\mathrm{Cl}$, confidence interval.

Table 3. Distribution on the results of fasting glucose and glycemic control indicators by the ranges for health check-up subjects

\begin{tabular}{|c|c|c|c|c|c|c|c|}
\hline \multirow{3}{*}{$\begin{array}{l}\text { Glucose range } \\
(\mathrm{mg} / \mathrm{dL})\end{array}$} & \multirow{3}{*}{$\begin{array}{l}\text { Test item } \\
\text { No. by range }\end{array}$} & \multicolumn{2}{|c|}{$1,5-\mathrm{AG}(\mathrm{mg} / \mathrm{mL})$} & \multicolumn{2}{|c|}{ Fructosamine (umol/L) } & \multicolumn{2}{|c|}{$\mathrm{HbA1c}(\%)$} \\
\hline & & -14 & $>14$ & $>285$ & -285 & $>6$ & -6 \\
\hline & & Positive & Negative & Positive & Negative & Positive & Negative \\
\hline$<100$ & 134 & 3 & 131 & 14 & 120 & 1 & 133 \\
\hline $100 \sim 125$ & 15 & 1 & 14 & 0 & 15 & 1 & 14 \\
\hline$>125$ & 4 & 2 & 2 & 2 & 2 & 2 & 2 \\
\hline Total & 153 & 6 & 147 & 16 & 137 & 4 & 149 \\
\hline
\end{tabular}

성 결과를 보였다. $100 \mathrm{mg} / \mathrm{dL}$ 이하 구간에서 $1,5-\mathrm{AG}$ 의 양성 결과 치 3 사례의 혈당치는 $70,74,98 \mathrm{mg} / \mathrm{dL}$ 이었다. 프록토사민은 혈 당 $100 \mathrm{mg} / \mathrm{dL}$ 이하 구간에서 14 건의 양성 사례를 보여주었고 공복 시 포도당 장애 선별 구간(100 125 mg/dL)에서는 양성 사례가 없었다.

혈당치 $100 \mathrm{mg} / \mathrm{dL}$ 이하, 공복 시 포도당 장애 선별 기준 구간 $(100 \sim 125 \mathrm{mg} / \mathrm{dL})$ 및 $126 \mathrm{mg} / \mathrm{dL}$ 이상의 각 구간의 공복 혈당과 각 혈당조절지표의 기본 통계치와 분포 양상을 상자 수염 그림(box whisker plot)으로 도식하였다(Fig. 4). $100 \mathrm{mg} / \mathrm{dL}$ 이하 구간과 공 복 시 포도당 장애 선별 기준 구간을 대상으로 각 혈당조절지표 결 과치를 t-test로 검정한 결과 1,5-AG만이 의미 있는 평균치의 차이 를 보였다 $(p<0.05)$ (Table 4). 또한 켄달 타우 일치도 검정 결과는 혈당 전체 범위에서 혈당 대 1,5-AG (Kendall's tau $=-0.1632$, $p=0.0030)$ 와 프록토사민 대 당화혈색소( $\operatorname{tau}=0.1338, p=0.0192$ ) 가 의미 있는 상관성이 있었다(Table 5). 구간 별로는 혈당치 100 $\mathrm{mg} / \mathrm{dL}$ 이하 구간에서 프록토사민 대 당화혈색소(tau=0.1405, $p=0.0214$ ), 혈당치 $100 \sim 125 \mathrm{mg} / \mathrm{dL}$ 구간에서는 혈당 대 $1,5-\mathrm{AG}$ (tau= $-0.3666, p=0.0635$ ), 프록토사민 대 1,5-AG (tau=0.3828, $p=0.0475$ )의 상관성이 있었다(Table 6). 따라서 평균치 분석과 상 관성 검정 결과로서 공복 시 포도당 장애 선별 구간에서는 혈당조 절표지 종목들 중 $1,5-\mathrm{AG}$ 가 공복 혈당과 가장 상관성이 있는 것으 로 평가하였다.

\section{고 찰}

당뇨병 진단을 위한 혈당 기준은 당뇨병 질환의 조기 선별의 필 요성이 높아짐에 따라 그 기준이 엄격해져 왔으며 일정 기간의 혈 당치 조절을 추적하는 방법으로 혈당조절지표들이 활발하게 사용 되고 있다. 2010년 ADA기준은 당화혈색소 기준(HbA1c 6.5\% 이 상)이 추가되어 혈당조절지표는 당뇨병의 경과 및 치료 관찰과 더 불어 진단에서도 중요한 의미를 갖게 되었다[8]. 혈당조절지표 중 가장 널리 이용되는 당화혈색소는 $\mathrm{Hb} \mathrm{A1}$ 의 $80 \%$ 를 차지하는 주요 분획으로 이루어져 있어 적혈구 질환 및 혈색소 이상, 그리고 투석 환자에서는 혈당조절의 정확한 반영이 되지 않는다[9]. 프록토사 민, 당화알부민, $1,5-\mathrm{AG}$ 는 이와 같은 당화혈색소 검사의 적용이 불 완전한 경우에 이용될 수 있다. 당화알부민과 1,5-AG는 혈당 변동 

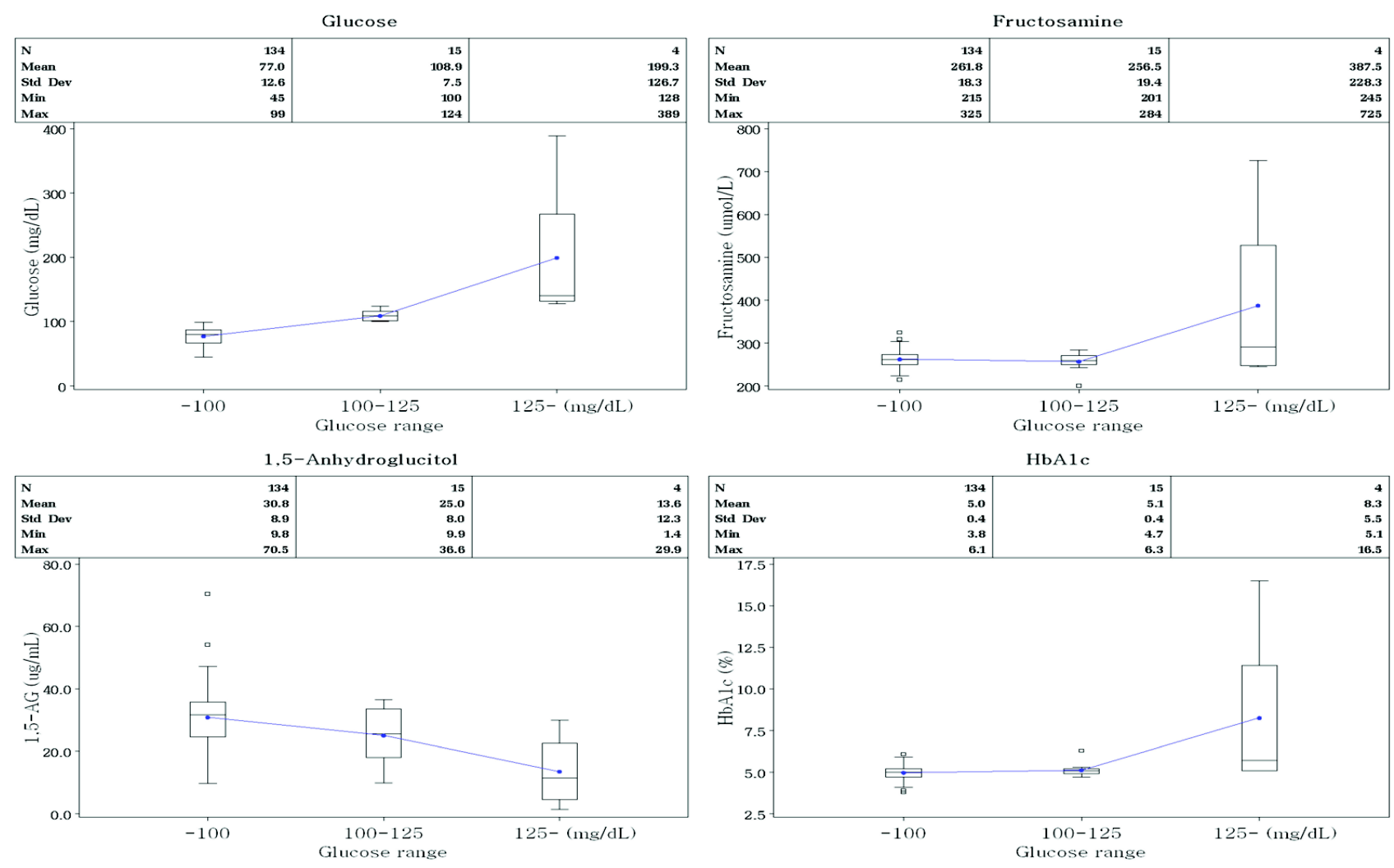

Fig. 4. Distribution of the level of the fasting blood glucose and the glycemic indicators for health check-up subjects. The average values of $1,5-\mathrm{AG}$ between the ranges of glucose level $100 \sim 125 \mathrm{mg} / \mathrm{dL}$ and $100 \mathrm{mg} / \mathrm{dL}$ or less were significantly different $(p<0.05)$.

Table 4. Independent samples t-test of glycemic indicators according to blood glucose range for health check-up subjects

\begin{tabular}{|c|c|c|c|c|c|c|}
\hline \multirow{2}{*}{$\begin{array}{c}\text { Glucose range }(\mathrm{mg} / \mathrm{dL}) \\
\text { Test item }\end{array}$} & \multicolumn{2}{|c|}{$<100(n=134)$} & \multicolumn{2}{|c|}{$100 \sim 125(n=15)$} & \multirow{2}{*}{ t value } & \multirow{2}{*}{$p$-value } \\
\hline & Mean & SD & Mean & SD & & \\
\hline $1,5-\mathrm{AG}(\mathrm{ug} / \mathrm{mL})$ & 30.8 & 8.92 & 25.0 & 7.96 & -2.66 & $0.0159^{*}$ \\
\hline Fructosamine (umol/L) & 261.8 & 18.28 & 256.5 & 19.43 & -1.06 & 0.2900 \\
\hline $\mathrm{HbA} 1 \mathrm{c}(\%)$ & 5.0 & 0.36 & 5.1 & 0.38 & 1.45 & 0.1492 \\
\hline
\end{tabular}

${ }^{*} p<0.05$.

Table 5. Correlation between fasting blood glucose and glycemic control indicators for 153 health check-up subjects

\begin{tabular}{|c|c|c|c|c|c|c|c|c|}
\hline & \multicolumn{2}{|c|}{ Glucose } & \multicolumn{2}{|c|}{$1,5-A G$} & \multicolumn{2}{|c|}{ Fructose } & \multicolumn{2}{|c|}{$\mathrm{HbA} 1 \mathrm{c}$} \\
\hline & tau & $p$-value & tau & $p$-value & tau & $p$-value & tau & $p$-value \\
\hline Glucose & 1 & & -0.1632 & $0.0030^{\star *}$ & -0.0314 & 0.5719 & 0.0990 & 0.0826 \\
\hline $1,5-A G$ & & & 1 & & 0.0871 & 0.1145 & -0.0162 & 0.7754 \\
\hline Fructose & & & & & 1 & & 0.1338 & $0.0192^{*}$ \\
\hline $\mathrm{HbA} 1 \mathrm{c}$ & & & & & & & 1 & \\
\hline
\end{tabular}

${ }^{*} p<0.05,{ }^{* *} p<0.01$.

Abbreviation: tau, Kendall rank correlation coefficient.

성을 잘 반영하는 지표로 알려져 있다[7]. 당화혈색소는 2,3 개월의 평균혈당을 반영하는 중기 혈당조절지표로서 사용되고 있으며 [10-12], 1,5-AG는 혈당의 대사상태의 변화에 더 민감하게 반응하
여 단기적 및 장기적으로 혈당량 조절에 대한 판정이나 당뇨와 관 련된합병증 예방을 위한추적에 유효하다고 보고되고 있다[5,13-16]. 프록토사민은 평균 혈당 또는 식전 혈당을 더 반영한다고 하였고 
Table 6. Correlation between fasting blood glucose and glycemic control indicators on the blood glucose range for health check-up subjects

\begin{tabular}{|c|c|c|c|c|c|c|c|}
\hline \multicolumn{2}{|c|}{ Test Item } & \multicolumn{2}{|c|}{$1,5-A G$} & \multicolumn{2}{|c|}{ Fructose } & \multicolumn{2}{|c|}{$\mathrm{HbA} 1 \mathrm{c}$} \\
\hline Glucose range (mg/dL) & No. of Results & tau & $p$-value & tau & $p$-value & tau & $p$-value \\
\hline Overall & 153 & -0.1632 & $0.0030^{\star *}$ & -0.0314 & 0.5719 & 0.0990 & 0.0826 \\
\hline$<100$ & 134 & -0.0777 & 0.1880 & $-0.0272^{*}$ & 0.6481 & 0.0429 & 0.4829 \\
\hline $100 \sim 125$ & 15 & -0.3666 & 0.0635 & -0.3385 & 0.0878 & -0.0313 & 0.8786 \\
\hline$>125$ & 4 & -0.6667 & 0.1742 & 0.6667 & 0.1742 & 0.9129 & 0.0710 \\
\hline
\end{tabular}

${ }^{*} p<0.05,{ }^{* *} p<0.01$.

Abbreviation: tau, Kendall rank correlation coefficient.

[5,17], 프록토사민과 당화혈색소는 혈당 변동성에 대한 상관성이 낮은 것으로 알려져 있다. $1,5-\mathrm{AG}$ 는 식후 혈당이나 높은 농도의 혈 당변화에 대한 반응성이 높고 결과치 변동폭이 넓어 치료 경과 추 적 시 유용하다고 보고되었다[5,7,18-21].

Frattali 등은 1,5-AG가 당뇨병 진단 목적으로 사용될 수 있다는 의견을 제시하였고[22], Yamanouchi 등은 당뇨병 검출에 있어 당 화혈색소, 프록토사민보다 효과적이라고 보고하였으며[15], Kim 등은 1,5-AG가 경증 및 중등도 당뇨병 환자에서 공복 혈당과 당화 혈색소는 상관관계가 있다고 보고하였다[12]. 본 연구에서도 $1,5-\mathrm{AG}$ 는 $100 \mathrm{mg} / \mathrm{dL}$ 이하 구간의 평균치 $30.8 \mathrm{ug} / \mathrm{mL}$ 에서 공복 시 포도당 장애의 선별 혈당 구간 $(100 \sim 125 \mathrm{mg} / \mathrm{dL})$ 의 25.0 $\mathrm{ug} / \mathrm{mL}$ 로 감소하여 $(p<0.05)$ 연구 대상의 혈당조절지표 중 공복 혈당치를 가장 잘 반영하는 종목으로 $1,5-\mathrm{AG}$ 가 평가되었다. 프록 토사민은 혈당 농도 $100 \mathrm{mg} / \mathrm{dL}$ 이하에 14건의 양성 결과 사례를 보 여주었는데, 문헌 보고에 따르면 프록토사민은 혈장 내 다른 물질 에 따라 농도가 변화할 수 있는 것으로도 알려져 있어[23], 저농도 혈당 구간에서 이러한 영향을 받았을 가능성이 추정되었다.

내당능 장애는 혈당조절 능력을 평가하는 전당뇨병 선별 기준이 지만 공복 혈당이 충분히 낮은 경우라면 경구 포도당 부하 검사를 위한 임상적 판단이 어려울 수 있다. 1,5-AG는 식후 혈당이나 당부 하 후 혈당치와 상관성이 있는 것으로 보고되고 있다[5,7,24,25]. 따라서 본 연구 결과에서 $100 \mathrm{mg} / \mathrm{dL}$ 이하 구간의 $1,5-\mathrm{AG}$ 양성 결 과 3 사례 $(70,74,98 \mathrm{mg} / \mathrm{dL})$ 는 내당능 장애 선별이 필요할 수 있을 것으로 사료되었다. 혈당과 혈당조절지표의 상관성 분석을 위해 시 행한, 전체 구간에 대한 켄달 타우 일치도 검정 결과에서 프록토사 민 및 당화혈색소의 상관성이 유의하지 않게 평가된 것은 연구 대 상이 건강검진 대상자로 참고치 상한 $(125 \mathrm{mg} / \mathrm{dL})$ 을 벗어나는 결 과치 사례가 4건으로 높은 농도의 결과치들이 제외되었기 때문으 로 생각되었다.

검사를 위한 금식 기준은 통상 8시간으로 알려져 있다[26]. 본 연 구에서 금식 여부는 채혈 환자에게 구두 질문을 통해 확인하였으므 로 금식 기준이 명확하게 적용되지는 못하였지만 금식에 따른 혈당
치 차이의 대체적인 경향을 파악을 하는데 도움이 되고자 하였다. 본 연구에서 10 대 이후 연령대가 증가함에 따라 중앙값과 $75 \%$ 백 분위수가 높아지는 것이 추정되어 크루스칼 왈리스 검정을 시행한 결과 비금식 군에서만 유의한 차이가 있는 것으로 평가되었다. 10 대 미만 연령대가 10대보다 중앙값이 높게 산출(106.5 vs. 103 $\mathrm{mg} / \mathrm{dL}$ )된 것은 영아기의 혈당 조절의 불완전성에 따른 것으로 추 정되며 $[27,28]$, 또한 각 연령대 별의 금식 군 연구 대상자 수가 충분 하지 못하여 추가 연구가 필요할 것으로 생각되었다. 저자들은 금 식 여부에 따른 혈당치 분포를 파악하기 위한 연구 방법으로 평균 치 또는 중앙값의 대표값을 비교 평가하였지만 성별, 임상과, 연령 대 및 금식 여부에 관계없이 당뇨병 환자가 해당 군에 포함되면 변 동성 요인이 될 수 있기 때문에 군 간 대표값 차이의 근본 이유는 연 령대 증가에 따라 비금식 상태에서 혈당치가 높아지는 것에 기인한 것으로 추정되었다. 저자들은 금식 여부에 따른 혈당치 분포와 연 령대에 따른 혈당치 변화의 통계적인 특성을 파악하여 당뇨병 선별 진단에 추가적인 정보를 제공하고자 하였다. 질환의 선별에는 개인 의 개별적 특질이 중요하므로 이를 감안한 임상적 판단이 이루어져 야 하겠다.

당뇨병 합병증이나 심혈관 질환의 발생에 식후 고혈당이 실제적 인 영향을 줄수 있는 것으로 알려져, 식후 고혈당 변화를 잘 반영하 는 당화알부민이나 1,5-AG에 대한 관심이 최근 높아지고 있다 $[5,7,29]$. 당뇨병 진단 검사로서 $1,5-\mathrm{AG}$ 검사의 우선적인 이용에는 다양한 의견이 있지만[15,22,24], 당뇨병 및 전당뇨병 선별 시 예민 도와 특이도를 높이는 차원에서 혈당조절지표를 병행 사용하는 필 요성에 대한 여러 보고들이 있었다[23,30,31]. 저자들은 당뇨병 선 별 검사로서 단기 혈당조절 능력이나 혈당 변동성을 잘 반영하는 혈당조절지표의 활용이 유용할 것으로 생각하였다. 본 연구에서 비 교 분석한 혈당조절지표 중 $1,5-\mathrm{AG}$ 가 공복 시 포도당 장애 구간에 서 공복 혈당치와 유의한 상관성이 있는 것으로 평가하였다. 


\section{요 약}

본 연구는 금식 여부에 따른 혈당치 분포 차이를 분석하였고 공 복 혈당치와 혈당조절지표인 당화혈색소, 프록토사민, 1,5-AG의 상관성을 분석하여 전당뇨병 선별에 필요한 추가 정보를 제공하고 자 하였다. 단국대학교병원에 내원한 707 명의 외래 환자를 금식 군 과 비금식 군으로 나누어 혈당 검사를 시행한 후 각 군의 혈당치 평 균을 산출하고 성별, 연령별 및 임상과 별 결과치 분포를 분석을 하 였다. 또한 건강검진을 목적으로 내원한 금식 상태의 153 명에 대해 혈당치와 당화혈색소, 프록토사민, 1,5-AG을 측정하여 혈당치와 혈당조절지표의 상관성을 평가하였다. 비금식 군의 혈당 평균치는 $111.9 \mathrm{mg} / \mathrm{dL}$, 금식 군은 $103.6 \mathrm{mg} / \mathrm{dL}$ 로서 유의한 차이가 있었고 $(p<0.05)$ 평균치 차이는 여자가 $4.8 \mathrm{mg} / \mathrm{dL}$ 로서 남자의 12.2 $\mathrm{mg} / \mathrm{dL}$ 보다 적었다. 연령대에 따른 중앙값의 차이는 비금식 군에서 만 유의한 차이가 있었고(Kruskal-Wallis test, $p<0.01$ ) 금식 군에 서는 유의하지 않았다. 공복 시 포도당 장애 선별 구간에서 혈당 농 도와 상관성이 높은 검사 종목은 $1,5-\mathrm{AG}$ 로 평가되었다. 저자들은 금식 여부에 따른 혈당치 분포의 차이를 외래 환자를 대상으로 분 석하였으며, 건강검진 대상자의 결과치 분석을 통해 1,5-AG가 프 록토사민, 당화혈색소보다 공복 혈당치와 유의한 상관성이 있는 것 으로 평가하였다. 당뇨병 선별 시 혈당 측정과 함께 단기 혈당 조절 능력을 반영하는 지표가 활용될 수 있을 것으로 사료된다.

\section{Acknowledgements: None \\ Funding: None \\ Conflict of interest: None}

\section{References}

1. World Health Organization. Definition, diagnosis, and classification of diabetes mellitus and its complications: Report of a WHO Consultation. Part 1. Diagnosis and classification of diabetes mellitus. Geneva: World Health Organization; 1999.

2. Harris MI, Eastman RC, Cowie CC, Flegal KM, Eberhardt MS. Comparison of diabetes diagnostic categories in the U.S. population according to 1997 American Diabetes Association and 1980-1985 World Health Organization diagnostic criteria. Diabetes Care. 1997;20:1859-1862.

3. Gabir MM, Hanson RL, Dabelea D, Imperatore G, Roumain J, Bennett PH, et al. The 1997 American Diabetes Association and 1999 World Health Organization criteria for hyperglycemia in the diagnosis and prediction of diabetes. Diabetes Care. 2000; 23:1108-1112.

4. Expert Committee on the Diagnosis and Classification of Diabetes Mellitus. Report of the expert committee on the diagnosis and classification of diabetes mellitus. Diabetes Care.
1997;20:1183-1197.

5. Dungan KM. 1,5-anhydroglucitol (Glyco-Mark ${ }^{\mathrm{TM}}$ ) as a marker of short-term glycemic control and glycemic excursions. Expert Rev Mol Diagn. 2008;8(1):9-19.

6. Kim CB. A determination of serum fructosamine in relation to blood glucose and glycosylated hemoglobin in diabetes mellitus. Korean Journal of Medical Technologists. 1989;21:8898.

7. Kim WJ, Park CY. Review of the potential glycemic markers glycated albumin and 1,5-anhydroglucitol. J Korean Diabetes. 2012;13:1-6.

8. Aldasouqi SA, Gossain VV. Update on diabetes diagnosis: A historical review of the dilemma of the diagnostic utility of glycohemoglobin A1c and a proposal for a combined glucose-A1c Diagnostic Method. Ann Saudi Med. 2012;32(3):229-235.

9. Sofronescu AG, Williams LM, Andrews DM, Zhu Y. Unexpected hemoglobin A1c results. Clin Chem. 2011;57(2):153-156.

10. Hom FG, Ettinger B, Lin MJ. Comparison of serum fructosamine vs glycohemoglobin as measures of glycemic control in a large diabetic population. Acta Diabetol. 1998;35:48-51.

11. Tahara Y, Shima K. Kinetics of HbA1c, glycated albumin, and fructosamine and analysis of their weight functions against preceding plasma glucose level. Diabetes Care. 1995;18:440-447.

12. Kim WJ, Park CY, Lee KB, Park SE, Rhee EJ, Lee WY, et al. Serum 1,5-anhydroglucitol concentrations are a reliable index of glycemic control in type 2 diabetes with mild or moderate renal dysfunction. Diabetes Care. 2012;35:281-286.

13. Dworacka M, Winiarska H. The application of plasma 1,5-anhydro-D-glucitol for monitoring type 2 diabetic patients. Dis Markers. 2005;21:127-132.

14. SKim MJ, Jung HS, Hwang-Bo Y, Cho SW, Jang HC, Kim SY, et al. Evaluation of 1,5-anhydroglucitol as a marker for glycemic variability in patients with type 2 diabetes mellitus. Acta Diabetol. 2013;50:505-510.

15. Yamanouchi T, Akanuma Y, Toyota T, Kuzuya T, Kawai T, Kawazu S, et al. Comparison of 1,5-Anhydroglucitol, HbA1c, and fructosamine for detection of diabetes mellitus. Diabetes. 1991; 40:52-57.

16. Yamanouchi T, Ogata N, Tagaya T, Kawasaki T, Sekino N, Funato $\mathrm{H}$, et al. Clinical usefulness of serum 1,5-anhydroglucitol in monitoring glycaemic control. Lancet. 1996;347:1514-1518.

17. Watanabe M, Kokubo Y, Higashiyama A, Ono Y, Miyamoto Y, Okamura T. Serum 1,5-anhydro-D-glucitol levels predict firstever cardiovascular disease: an 11-year population-based cohort study in Japan, the Suita study. Atherosclerosis. 2011; 216(2):477-483.

18. Dabrowska AM, Tarach JS, Kurowska M. 1,5-Anhydroglucitol $(1,5-\mathrm{AG})$ and Its usefulness in clinical practice. Medical and Biological Sciences. 2012;26(3):11-17.

19. Yamanouchi T, Ogata N, Tagaya T, Kawasaki T, Sekino N, Funato H, et al. Clinical usefulness of serum 1,5-anhydroglucitol in monitoring glycaemic control. Lancet. 1996:347;1514-1518.

20. Suwa T, Ohta A, Matsui T, Koganei R, Kato H, Kawata T, et al. Relationship between clinical markers of glycemia and glucose excursion evaluated by continuous glucose monitoring (CGM). Endocr J. 2010;57:135-140.

21. Ryu JR, Ahn JS, Park JY, Nam HC, Kim CS. Comparison of 
1,5-anhydroglucitol and HbA1c as clinical marker of glycemic control in type II diabetes mellitus patients. Korean J Clin Lab Sci. 2002;34:101-104.

22. Frattali AL, Wolf BA. 1,5-anhydroglucitol: a novel serum marker for screening and monitoring diabetes mellitus? Clin Chem. 1994; 40:1991-1993.

23. Armbruster DA. Fructosamine: structure, analysis, and clinical usefulness. Clin Chem. 1987;33:2153-2163.

24. Gerstein HC. Fasting versus postload glucose Levels: Why the controversy? Diabetes Care. 2001;24:1855-1857.

25. Robertson DA, Alberti KG, Dowse GK, Zimmet P, Tuomilehto J, Gareeboo H. Is serum anhydroglucitol an alternative to the oral glucose tolerance test for diabetes screening? The Mauritius Noncommunicable Diseases Study Group. Diabet Med. 1993; 10:56-60.

26. Sacks DB, Bruns DE, Goldstein DE, Maclaren NK, McDonald JM, Parrott M. Guidelines and recommendations for laboratory analysis in the diagnosis and management of diabetes mellitus.
Clin Chem. 2002; 48:436-472.

27. Kweon YS, Han YJ, Kim DC, Song HS. Effect of preoperative fasting time on blood glucose concentrations in children. Korean J Anesthesiol. 2000;39(4):528-533.

28. Kim EY. Glucose metabolism and evaluation of hypoglycemia in neonate. Korean J Pediatr. 2007;50:223-229.

29. Yamanouchi T, Inoue T, Ogata E, Kashiwabara A, Ogata N, Sekino N, et al. Post-load glucose measurements in oral glucose tolerance tests correlate well with 1,5-anhydroglucitol, an indicator of overall glycaemic state, in subjects with impaired glucose tolerance. Clin Sci. 2001;101:227-233.

30. Parappil A, Doi SA, Al-Shoumer KA. Diagnostic criteria for diabetes revisited: making use of combined criteria. BMC Endocr Disord. 2002;2(1):1.

31. Kim KW, Kim YL, Kim SH, Kim Y, Cho IJ. Comparison of hemoglobin A1c and fasting blood glucose for diagnosis of diabetes in Korea. Korean J Fam Pract. 2016;6(5):524-527. 